\title{
Prevalence of Portuguese Children Exposed to Secondhand Smoke at Home and in the Car
}

\section{Prevalência de Crianças Portuguesas Expostas ao Fumo Ambiental do Tabaco em Casa e no Carro}

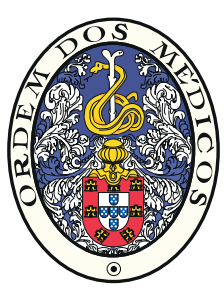

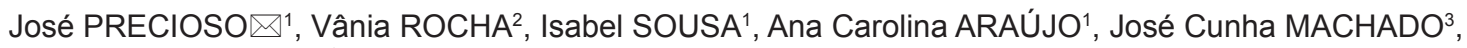 \\ Henedina ANTUNES ${ }^{4,5,6}$ \\ Acta Med Port 2019 Jul-Aug;32(7-8):499-504 - https://doi.org/10.20344/amp.11655
}

\section{ABSTRACT}

Introduction: Children's exposure to secondhand smoke is a cause of serious health problems and infant morbidity. This is the first nationally representative study conducted in Portugal to describe the prevalence of children exposed to secondhand smoke at home and in the car.

Material and Methods: This is a descriptive cross-sectional study with a representative sample of 2396 Portuguese children aged 0 to 9 years old, stratified by age and administrative region NUTS II. Questionnaires were administered between January and September 2016.

Results: Results showed that $6.1 \%$ of mothers and $11.2 \%$ of fathers reported smoking at home. It was found that $4.5 \%$ of mothers and $8.3 \%$ of fathers reported smoking in the car. Results also showed that $5.4 \%$ of children were double exposed to secondhand smoke at home and in the car. Children whose parents were smokers and had a lower level of education were more exposed to secondhand smoke at home.

Discussion: Children's exposure to secondhand smoke has been decreasing in Portugal. Parental smoking and a low educational level were risk factors for children's exposure to secondhand smoke at home.

Conclusion: The main source of children's exposure to secondhand smoke is parental smoking. As such, it is crucial to implement effective measures to control parental smoking. It is necessary to promote smoking cessation among parents and to ban smoking inside the car.

Keywords: Air Pollution, Indoor; Automobiles; Child; Portugal; Tobacco Smoke Pollution

\section{RESUMO}

Introdução: A exposição das crianças ao fumo ambiental do tabaco é uma importante causa de graves problemas de saúde e morbilidade infantil. Este é o primeiro estudo com representatividade nacional realizado em Portugal a descrever a prevalência de crianças expostas ao fumo ambiental do tabaco em casa e no carro.

Material e Métodos: Trata-se de um estudo transversal descritivo que inclui uma amostra representativa de 2396 crianças portuguesas dos 0 aos 9 anos de idade, estratificada por idade e por região administrativa NUTS II. A aplicação de questionários decorreu entre janeiro e setembro de 2016.

Resultados: Verifica-se que $6,1 \%$ das mães e $11,2 \%$ dos pais fumam no domicílio. Constata-se que $4,5 \%$ das mães e $8,3 \%$ dos pais fumam no carro. Verifica-se também que $5,4 \%$ das crianças estão duplamente expostas ao fumo ambiental do tabaco em casa e no carro. As crianças cujos pais são fumadores e com menor nível de escolaridade, estão mais expostas ao fumo ambiental do tabaco em casa.

Discussão: A exposição das crianças ao fumo ambiental do tabaco tem diminuído em Portugal. Ainda assim, o consumo de tabaco dos pais e um baixo nível de escolaridade são fatores de risco para a exposição das crianças em casa.

Conclusão: Uma vez que a principal fonte de exposição das crianças ao fumo ambiental do tabaco é o tabagismo dos pais, é necessário promover a cessação tabágica junto dos mesmos, assim como implementar a proibição de fumar no carro.

Palavras-chave: Automóveis; Criança; Poluição do Ar em Ambientes Fechados; Poluição por Fumo de Tabaco; Portugal

\section{INTRODUCTION}

Secondhand smoke (SHS) is a mixture of solid and liquid gases released by the combustion of tobacco and by the exhaled smoke from the smokers' lungs. ${ }^{1}$ SHS contains more than 4000 chemicals, and 50 of these substances are carcinogenic. ${ }^{2,3}$ According to the US Environmental Protection Agency, SHS is responsible for more deaths than all other forms of air pollution combined. ${ }^{4}$ For this reason, SHS has been included in the Group A of carcinogens by the United States Environmental Protection Agency. ${ }^{3}$ The US Surgeon General Report reveals that there is sufficient evidence to attribute a cause and effect relationship between SHS and lung cancer. ${ }^{3}$

Children and newborns are particularly vulnerable to the negative effects of SHS, as their respiratory system and immune system are still developing. ${ }^{3,5}$ More than 600000 non-smokers die worldwide each year due to SHS and $28.0 \%$ of these deaths occur in children. ${ }^{6}$ Children exposed

1. Instituto de Educação. Universidade do Minho. Braga. Portugal.

2. Centro de Psicologia. Universidade do Porto. Porto. Portugal.

3. Instituto de Ciências Sociais. Universidade do Minho. Braga. Portugal.

4. Serviço de Pediatria. Hospital de Braga. Braga. Portugal.

5. Instituto de Ciências da Vida e da Saúde (ICVS). Escola de Ciências da Saúde da Universidade do Minho. Braga. Portugal.

6. Laboratório associado ICVS/3B's. Braga/Guimarães. Braga. Portugal.

$\triangle$ Autor correspondente: José Precioso. precioso@ie.uminho.pt

Recebido: 09 de dezembro de 2018 - Aceite: 23 de janeiro de 2019 | Copyright @ Ordem dos Médicos 2019 
to SHS present more chronic symptoms related to respiratory diseases (cough, wheezing and dyspnea), ${ }^{7}$ higher risk of lower respiratory tract infections (pneumonia and bronchiolitis), and an increased risk of recurrent otitis and asthma attacks. ${ }^{3}$

According to the World Health Organization, 700 million children are exposed to SHS at home. ${ }^{8}$ In addition to home exposure, children may also be exposed to SHS inside the car. $^{9}$ In fact, motor vehicles are microenvironments where passengers can be exposed to high concentrations of SHS if someone smokes inside them. ${ }^{10,11}$

According to Eurobarometer, in 2006, $71 \%$ of Portuguese participants stated that smoking was allowed at home, but in 2009 this percentage has decreased to $34 \% .^{12}$ In Portugal, $13 \%$ of smokers smoke in the car, even with children on board. ${ }^{12}$ Few studies have assessed, in Portugal, the exposure of children to SHS at home and inside the car.

This is the first nationally representative study conducted in Portugal to describe the prevalence of children (0 to 9 years old) exposed to SHS at home and in the car, and to analyse factors associated with children's exposure to SHS at home and in the car.

\section{MATERIAL AND METHODS Participants}

This is a descriptive cross-sectional study with a representative sample of Portuguese children from 0 to 9 years old, stratified by age and by region according to the Nomenclature of Territorial Units for Statistics (NUTS II) (North, Center, Lisbon Metropolitan area, Alentejo, Algarve, Autonomous Region of Madeira, and Autonomous Region of the Azores), based on estimated resident population in December 31, 2014. The overall sample was estimated from a population of 949567 according to a $95 \%$ confidence interval and a maximum error of $2 \%$. Thus, a total of 2396 children were included in the study, divided proportionally by age ( 0 to 9 years old) and by the seven administrative regions NUTS II.

The overall sample was divided into three subsamples, according to the place where the data collection took place: the data of children up to 3 years of age was collected at health centers ( $n=885)$; the data of children between 4 and 5 years old were collected at kindergartens $(n=492)$; and the data of children between 6 and 9 years old were collected at elementary schools $(n=1019)$.

\section{Instrument}

A self-reported questionnaire was administered to parents of children from 0 to 9 years old. The questionnaire was based on the Changes in Child Exposure to Environmental Tobacco Smoke-Wales questionnaire (CHETS), which has been validated for the Portuguese population and used in previous studies to assess children's exposure to SHS..$^{13,14}$ The questionnaire contained multiple choice questions and open-ended questions. Core questions assessed: sociodemographic variables (age, gender, household members, parents' level of education, place where children live), parental/other relatives smoking [(e.g. Who of the following children's household members smoke (father, mother, siblings)?]. Answer: "does not smoke", "yes, sometimes", "yes, every day" or "I don't know/does not live in my house"), children's exposure to SHS at home (Who of the following children's household members smoke at home (father, mother, siblings,...)? ("does not smoke", "yes, every day", "yes, sometimes" and "does not smoke at home" or "I don't know/ does not live in my house"), and children's exposure to SHS in the car (e.g., Who of the following children's household members smoke in the car (father, mother, siblings,...)? Answer: "does not smoke", "yes, every day", "yes, sometimes" and "does not smoke in the car" or "I don't know/does not travel by car").

\section{Procedure}

The data collection took place from February to September 2016 at health centers, and from January to August 2016 at kindergartens and elementary schools. The study was approved by the ethics committee of the Regional Health Administration of each administrative region, and by the directors of all elementary schools and kindergartens included in the study.

The selected schools and kindergartens were contacted via email and telephone in order to obtain authorization to participate in the study. The questionnaires were delivered by a researcher to the directors of each elementary school and kindergarten and to the teachers of the selected classes. Teachers were informed by a researcher about the pro-

Table 1 - Sample stratified by age and NUTS II

\begin{tabular}{lccccccccccc}
\hline NUTS II & $\mathbf{0}$ & $\mathbf{1}$ & $\mathbf{2}$ & $\mathbf{3}$ & $\mathbf{4}$ & $\mathbf{5}$ & $\mathbf{6}$ & $\mathbf{7}$ & $\mathbf{8}$ & $\mathbf{9}$ & Total \\
\hline North & 66 & 67 & 72 & 79 & 81 & 79 & 83 & 82 & 86 & 90 & 785 \\
Center & 39 & 40 & 44 & 46 & 48 & 46 & 49 & 49 & 51 & 53 & 465 \\
Lisbon & 70 & 68 & 74 & 78 & 81 & 77 & 79 & 76 & 76 & 77 & 756 \\
Alentejo & 13 & 13 & 15 & 16 & 16 & 15 & 16 & 16 & 16 & 17 & 153 \\
Algarve & 10 & 9 & 10 & 11 & 12 & 11 & 12 & 12 & 12 & 12 & 111 \\
Azores & 6 & 6 & 6 & 7 & 7 & 7 & 7 & 7 & 7 & 7 & 67 \\
Madeira & 4 & 5 & 5 & 6 & 6 & 6 & 6 & 7 & 7 & 7 & 59 \\
Total & 208 & 208 & 226 & 243 & 251 & 241 & 252 & 249 & 255 & 263 & 2396 \\
\hline
\end{tabular}

NUTS: Nomenclature of Territorial Units for Statistics; Lisbon: Lisbon Metropolitan area; Azores: Autonomous Region of the Azores; Madeira: Autonomous Region of Madeira 
cedure of administering the questionnaires, according to a protocol that included practical instructions. The teachers delivered the questionnaire and an informed consent form to the children, who in turn took them home to be filled and signed by their parents, within a week.

Randomly selected health centers were contacted via telephone and email, in order to obtain authorization of the directors of the health centers to participate in the study. The questionnaires were delivered by a researcher to the nurses responsible for each health center, who were informed about the procedure of administering the questionnaire, according to a protocol that included practical instructions. Nurses administered the questionnaire and delivered an informed consent form to the child's father or mother during the appointment at the health center.

\section{Statistical analysis}

Data were analyzed using the Statistical Package for the Social Sciences (SPSS), 24.0 version for Windows. For statistical analysis, we analyzed frequencies, contingency tables, and performed chi-square tests. A significance level of 0.05 was considered.

\section{RESULTS}

Table 2 shows the prevalence of Portuguese children from 0 to 9 years old exposed to SHS at home: $11.2 \%$ of the fathers and $6.1 \%$ of the mothers reported smoking at home. It should be noted that $14.3 \%$ children are exposed to SHS at home, daily $(5.8 \%)$ or occasionally $(8.5 \%)$, because at least one of the household members, often the father or the mother, smoked at home.

Table 3 shows the prevalence of children from 0 to 9 years old exposed to SHS at home by their household members, according to the parents' level of education. Exposure to SHS is higher among children whose parents have a lower level of education (19.6\%) than among children whose parents have a higher level of education (6.2\%). The prevalence of children exposed to SHS by their fathers is higher among children whose fathers have a lower level of education $(18.5 \%)$, than among children whose fathers have a higher level of education (4.8\%). The prevalence of children exposed to SHS by their mothers is higher among children whose mothers have a lower level of education (9.2\%), than among children whose mothers have a higher level of education (3.3\%).

Table 4 shows the prevalence of children from 0 to 9 years old exposed to SHS at home, according to the parents' smoking status (children whose parents are non-smokers vs. children who have at least one parent who is a smoker) by region. There were significant differences regarding children's exposure to SHS at home between parents who were smokers and parents who were non-smokers. Children who had at least one smoking parent were more exposed to SHS at home $(29.1 \%)$ than children whose parents were non-smokers $(2.1 \%)(p<0.001)$. This pattern was common in all regions of the country, and statistically significant in

Table 2 - Prevalence of children from 0 to 9 years old exposed to SHS at home

\begin{tabular}{|c|c|c|c|c|c|c|c|c|c|c|c|c|c|c|c|c|}
\hline & \multicolumn{4}{|c|}{$0-3$ years old } & \multicolumn{4}{|c|}{$4-5$ years old } & \multicolumn{4}{|c|}{$6-9$ years old } & \multicolumn{4}{|c|}{ Total } \\
\hline & $\mathbf{n}$ & $\begin{array}{l}\text { DI } \\
\%\end{array}$ & $\begin{array}{l}\text { Oc } \\
\%\end{array}$ & $\begin{array}{l}\mathrm{Tt} \\
\%\end{array}$ & $\mathbf{n}$ & $\begin{array}{l}\text { DI } \\
\%\end{array}$ & $\begin{array}{l}\text { Oc } \\
\%\end{array}$ & $\begin{array}{l}\mathrm{Tt} \\
\%\end{array}$ & $\mathbf{n}$ & $\begin{array}{l}\text { DI } \\
\%\end{array}$ & $\begin{array}{l}\text { Oc } \\
\%\end{array}$ & $\begin{array}{l}\mathrm{Tt} \\
\%\end{array}$ & $\mathbf{n}$ & $\begin{array}{l}\text { DI } \\
\%\end{array}$ & $\begin{array}{l}\text { Oc } \\
\%\end{array}$ & $\begin{array}{l}\mathrm{Tt} \\
\%\end{array}$ \\
\hline $\begin{array}{l}\text { Father or stepfather } \\
\text { or mother's partner }\end{array}$ & 781 & 5.5 & 6.8 & 12.3 & 309 & 4.9 & 8.4 & 13.3 & 845 & 3.4 & 5.9 & 9.3 & 1935 & 4.5 & 6.7 & 11.2 \\
\hline $\begin{array}{l}\text { Mother or stepmother } \\
\text { or father's partner }\end{array}$ & 745 & 1.5 & 3.8 & 5.3 & 276 & 2.9 & 6.2 & 9.1 & 813 & 2.2 & 3.8 & 6.0 & 1834 & 2.0 & 4.1 & 6.1 \\
\hline Siblings & 516 & 0.2 & 0.2 & 0.4 & 194 & 1.0 & 0.5 & 1.5 & 588 & 0.2 & 0.3 & 0.5 & 1298 & 0.3 & 0.3 & 0.6 \\
\hline Grandparents & 473 & 1.1 & 1.7 & 2.8 & 142 & 1.4 & 1.4 & 2.8 & 456 & 1.3 & 2.0 & 3.3 & 1071 & 1.2 & 1.8 & 3.0 \\
\hline Other people & 439 & 2.7 & 2.7 & 5.4 & 120 & - & 4.2 & 4.2 & 362 & 0.6 & 1.7 & 2.3 & 921 & 1.5 & 2.5 & 4.0 \\
\hline At least one parent & 799 & 5.8 & 7.6 & 13.4 & 320 & 5.9 & 9.7 & 15.6 & 911 & 4.0 & 6.9 & 10.9 & 2030 & 5.0 & 7.6 & 12.6 \\
\hline $\begin{array}{l}\text { At least one } \\
\text { household member }\end{array}$ & 808 & 7.1 & 8.7 & 15.8 & 321 & 6.2 & 10.6 & 16.8 & 926 & 4.6 & 7.7 & 12.3 & 2055 & 5.8 & 8.5 & 14.3 \\
\hline
\end{tabular}

SHS: secondhand smoke; DI: daily; Oc: occasional; Tt: total

Table 3- Prevalence of children from 0 to 9 years old exposed to SHS at home, considering household members' level of education

\begin{tabular}{|c|c|c|c|c|c|c|c|c|c|c|c|c|c|c|c|c|}
\hline & \multicolumn{4}{|c|}{$\leq 9$ ys } & \multicolumn{4}{|c|}{$10-12$ ys } & \multicolumn{4}{|c|}{$>12$ ys } & \multicolumn{4}{|c|}{ Total } \\
\hline & $\mathbf{n}$ & $\begin{array}{l}\text { DI } \\
\%\end{array}$ & $\begin{array}{l}\text { Oc } \\
\%\end{array}$ & $\begin{array}{l}\mathrm{Tt} \\
\%\end{array}$ & $\mathbf{n}$ & $\begin{array}{l}\text { DI } \\
\%\end{array}$ & $\begin{array}{l}\mathrm{Oc} \\
\%\end{array}$ & $\begin{array}{l}\mathrm{Tt} \\
\%\end{array}$ & $\mathbf{n}$ & $\begin{array}{l}\text { DI } \\
\%\end{array}$ & $\begin{array}{l}\mathrm{Oc} \\
\%\end{array}$ & $\begin{array}{l}\mathrm{Tt} \\
\%\end{array}$ & $\mathbf{n}$ & $\begin{array}{l}\text { DI } \\
\%\end{array}$ & $\begin{array}{l}\mathrm{Oc} \\
\%\end{array}$ & $\begin{array}{l}\mathrm{Tt} \\
\%\end{array}$ \\
\hline $\begin{array}{l}\text { Father or stepfather } \\
\text { or mother's partner }\end{array}$ & 535 & 6.2 & 12.3 & 18.5 & 663 & 4.7 & 7.7 & 12.4 & 728 & 3.2 & 1.6 & 4.8 & 1926 & 4.5 & 6.7 & 11.2 \\
\hline $\begin{array}{l}\text { Mother or stepmother } \\
\text { or father's partner }\end{array}$ & 503 & 2.6 & 6.6 & 9.2 & 631 & 1.9 & 5.1 & 7.0 & 691 & 1.7 & 1.6 & 3.3 & 1825 & 2.0 & 4.2 & 6.2 \\
\hline At least one parent & 573 & 7.2 & 12.4 & 19.6 & 697 & 4.9 & 9.2 & 14.1 & 751 & 3.5 & 2.7 & 6.2 & 2021 & 5.0 & 7.7 & 12.7 \\
\hline $\begin{array}{l}\text { At least one } \\
\text { household member }\end{array}$ & 590 & 9.2 & 13.9 & 23.1 & 704 & 5.4 & 9.7 & 15.1 & 752 & 3.7 & 3.1 & 6.8 & 2046 & 5.9 & 8.5 & 14.4 \\
\hline
\end{tabular}

SHS: secondhand smoke; DI: daily; Oc: occasional; Tt: total 
Table 4 - Prevalence of children from 0 to 9 years old exposed to SHS at home according to parents' tobacco consumption, by region

\begin{tabular}{|c|c|c|c|c|c|c|}
\hline & Parents & $\mathrm{n}$ & $\begin{array}{c}\text { Not exposed to } \\
\text { SHS at home } \\
\%\end{array}$ & $\begin{array}{c}\text { Exposed to } \\
\text { SHS at home } \\
\%\end{array}$ & $x^{2}$ & $p$ \\
\hline North & $\begin{array}{l}\text { Non-smokers } \\
\text { At least one smoker }\end{array}$ & $\begin{array}{l}309 \\
170\end{array}$ & $\begin{array}{l}97.7 \\
66.5\end{array}$ & $\begin{array}{c}2.3 \\
33.5\end{array}$ & 92.6 & $<0.001$ \\
\hline Center & $\begin{array}{l}\text { Non-smokers } \\
\text { At least one smoker }\end{array}$ & $\begin{array}{l}170 \\
108\end{array}$ & $\begin{array}{l}98.8 \\
70.4\end{array}$ & $\begin{array}{c}1.2 \\
29.6\end{array}$ & 49.8 & $<0.001$ \\
\hline Lisbon & $\begin{array}{l}\text { Non-smokers } \\
\text { At least one smoker }\end{array}$ & $\begin{array}{l}118 \\
118\end{array}$ & $\begin{array}{l}97.5 \\
66.1\end{array}$ & $\begin{array}{c}2.5 \\
33.9\end{array}$ & 38.9 & $<0.001$ \\
\hline Alentejo & $\begin{array}{l}\text { Non-smokers } \\
\text { At least one smoker }\end{array}$ & $\begin{array}{l}44 \\
48\end{array}$ & $\begin{array}{l}95.5 \\
83.3\end{array}$ & $\begin{array}{c}4.5 \\
16.7\end{array}$ & 3.5 & 0.062 \\
\hline Algarve & $\begin{array}{l}\text { Non-smokers } \\
\text { At least one smoker }\end{array}$ & $\begin{array}{l}29 \\
31\end{array}$ & $\begin{array}{c}100.0 \\
87.1\end{array}$ & $\begin{array}{c}0 \\
12.9\end{array}$ & 4.0 & 0.045 \\
\hline Azores & $\begin{array}{l}\text { Non-smokers } \\
\text { At least one smoker }\end{array}$ & $\begin{array}{l}16 \\
20\end{array}$ & $\begin{array}{l}100.0 \\
75.0\end{array}$ & $\begin{array}{c}0 \\
25.0\end{array}$ & 4.6 & 0.031 \\
\hline Madeira & $\begin{array}{l}\text { Non-smokers } \\
\text { At least one smoker }\end{array}$ & $\begin{array}{l}24 \\
13\end{array}$ & $\begin{array}{l}95.8 \\
84.6\end{array}$ & $\begin{array}{c}4.2 \\
15.4\end{array}$ & 1.4 & 0.233 \\
\hline Total & $\begin{array}{l}\text { Non-smokers } \\
\text { At least one smoker }\end{array}$ & $\begin{array}{l}710 \\
508\end{array}$ & $\begin{array}{l}97.9 \\
70.9\end{array}$ & $\begin{array}{c}2.1 \\
29.1\end{array}$ & 186.5 & $<0.001$ \\
\hline
\end{tabular}

SHS: secondhand smoke; Lisbon: Lisbon Metropolitan area; Azores: Autonomous Region of the Azores; Madeira: Autonomous Region of Madeira

the following regions: North $(p<0.001)$, Center $(p<0.001)$, Lisbon Metropolitan area $(p<0.001)$, Algarve $(p<0.05)$, and Autonomous Region of the Azores $(p<0.05)$.

Regarding the prevalence of children from 0 to 9 years old exposed to SHS inside the car, Table 5 shows that $4.5 \%$ of mothers and $8.3 \%$ of fathers smoked inside the car. At least one parent smoked in the car in $9.0 \%$ of families.

Regarding the overall prevalence of children from 0 to 9 years old exposed to SHS by household members (father, mother or other), Table 6 shows that $5.4 \%$ of children are simultaneously exposed to SHS at home and inside the car (double exposure).

\section{DISCUSSION}

Children's exposure to SHS is a cause of serious health problems and infant morbidity. ${ }^{15}$ This study aimed to describe the prevalence of children (0 to 9 years old) exposed to SHS at home and in the car.

In the present study, $14.3 \%$ of Portuguese children aged 0 to 9 were exposed to SHS at home (daily or occa-
sionally).In Portugal, a study with a representative sample of 4 th grade students showed that $32.6 \%$ children were exposed to SHS at home. ${ }^{16}$ The prevalence of children's exposure to SHS at home in Portugal was lower than the global prevalence in 2007: it was estimated that $50 \%$ of children were exposed to SHS worldwide, mainly at home by at least one of the household members. ${ }^{9,15}$ According to Vitória, Nunes, and Precioso, the risk of children's exposure to SHS at home increases when parents have a low educational level. ${ }^{17}$ These results have also been found in the present study, confirming the social inequalities associated with smoking. Parental smoking, a low socioeconomic status and being less educated were all frequently and consistently found to be independently associated with children's SHS exposure at home. ${ }^{18}$ Parent's smoking at home is a risk factor for children becoming smokers in the future. ${ }^{19}$ Precioso, Macedo, and Rebelo found that within the group of students whose parents were smokers, the prevalence of students who smoked was significantly higher if parents smoked at home than among students whose parents were

Table 5 - Prevalence of children from 0 to 9 years old exposed to SHS inside the car

\begin{tabular}{|c|c|c|c|c|c|c|c|c|c|c|c|c|c|c|c|c|}
\hline & \multicolumn{4}{|c|}{$0-3$ years old } & \multicolumn{4}{|c|}{$4-5$ years old } & \multicolumn{4}{|c|}{$6-9$ years old } & \multicolumn{4}{|c|}{ Total } \\
\hline & $\mathbf{n}$ & $\begin{array}{l}\text { DI } \\
\%\end{array}$ & $\begin{array}{l}\mathrm{Oc} \\
\%\end{array}$ & $\begin{array}{l}\mathrm{Tt} \\
\%\end{array}$ & $\mathbf{n}$ & $\begin{array}{l}\text { DI } \\
\%\end{array}$ & $\begin{array}{l}\text { Oc } \\
\%\end{array}$ & $\begin{array}{l}\mathrm{Tt} \\
\%\end{array}$ & $\mathbf{n}$ & $\begin{array}{l}\text { DI } \\
\%\end{array}$ & $\begin{array}{l}\text { Oc } \\
\%\end{array}$ & $\begin{array}{l}\mathrm{Tt} \\
\%\end{array}$ & $\mathbf{n}$ & $\begin{array}{l}\text { DI } \\
\%\end{array}$ & $\begin{array}{l}\mathrm{Oc} \\
\%\end{array}$ & $\begin{array}{l}\mathrm{Tt} \\
\%\end{array}$ \\
\hline $\begin{array}{l}\text { Father or stepfather } \\
\text { or mother's partner }\end{array}$ & 777 & 1.5 & 6.3 & 7.8 & 321 & 1.6 & 7.5 & 9.1 & 844 & 1.5 & 7.0 & 8.5 & 1942 & 1.5 & 6.8 & 8.3 \\
\hline $\begin{array}{l}\text { Mother or stepmother } \\
\text { or father's partner }\end{array}$ & 747 & 0.5 & 3.3 & 3.8 & 291 & 1.0 & 4.1 & 5.1 & 804 & 0.9 & 4.0 & 4.9 & 1842 & 0.8 & 3.7 & 4.5 \\
\hline Siblings & 505 & 0.2 & 0.2 & 0.4 & 201 & - & - & - & 572 & 0.2 & - & 0.2 & 1278 & 0.2 & 0.1 & 0.3 \\
\hline Grandparents & 477 & 0.2 & 1.9 & 2.1 & 159 & - & 0.6 & 0.6 & 490 & 0.2 & 1.6 & 1.8 & 1126 & 0.2 & 1.6 & 1.8 \\
\hline Other people & 464 & 2.2 & - & 2.2 & 143 & 2.8 & - & 2.8 & 415 & 1.7 & - & 1.7 & 1022 & 2.1 & - & 2.1 \\
\hline At least one parent & 791 & 1.8 & 6.6 & 8.4 & 335 & 1.8 & 7.8 & 9.6 & 907 & 1.7 & 7.8 & 9.5 & 2033 & 1.7 & 7.3 & 9.0 \\
\hline At least one person & 801 & 1.9 & 7.9 & 9.8 & 336 & 1.8 & 8.3 & 10.1 & 923 & 1.7 & 8.5 & 10.2 & 2060 & 1.8 & 8.2 & 10.0 \\
\hline
\end{tabular}

SHS: secondhand smoke; DI: daily; Oc: occasional; Tt: total 
Table 6 - Overall prevalence of children from 0 to 9 years old exposed to SHS at home and in the car, by household members (mother, father, or other)

\begin{tabular}{|c|c|c|c|c|c|c|}
\hline \multirow[b]{2}{*}{ Children's age } & \multicolumn{2}{|c|}{ Home } & \multicolumn{2}{|c|}{ Car } & \multicolumn{2}{|c|}{ Home and car } \\
\hline & $\mathbf{n}$ & $\%$ & $\mathbf{n}$ & $\%$ & $\mathbf{n}$ & $\%$ \\
\hline $0-3$ years old & 807 & 15.7 & 796 & 9.8 & 813 & 5.9 \\
\hline $4-5$ years old & 321 & 16.8 & 331 & 10.3 & 339 & 5.6 \\
\hline $6-9$ years old & 923 & 12.4 & 912 & 10.3 & 952 & 4.8 \\
\hline Total & 2051 & 14.4 & 2039 & 10.1 & 2104 & 5.4 \\
\hline
\end{tabular}

smokers but did not smoke at home. ${ }^{20}$ This data allow us to conclude that parental smoking, particularly at home, is a risk factor related to children's tobacco consumption. The data from the present study revealed large differences in the prevalence of children's exposure to SHS at home between children of non-smoking parents and children with at least one smoking parent. These differences were statistically significant in the total sample and in most regions assessed (North, Center, Lisbon Metropolitan area, Algarve, and Autonomous Region of the Azores). In general, $2.1 \%$ of the children of non-smoking parents are exposed to SHS at home, whereas this prevalence is $29.1 \%$ among children with at least one parent smoker. This pattern was common in all regions of the country. In most regions of the country, more than $25 \%$ of children, with at least one smoking parent, were exposed to SHS, which means that one in four children are exposed to SHS at home.

In addition to home exposure, children may also be exposed to SHS in the car. ${ }^{9}$ According to data from the European Commission, 13\% of Portuguese smokers reported smoking inside the car, even in the presence of children. ${ }^{12}$ A study conducted in Braga in 2010 revealed that $25.1 \%$ of children, who travelled by car, reported being exposed to SHS in the vehicle. ${ }^{21}$ In the present study, prevalence estimates were slightly lower: in $9.0 \%$ of families, at least one parent smoked inside the car.

The present study found that $5.4 \%$ of children are simultaneously exposed to SHS at home and inside the car (double exposure), which is lower than the percentage of $17.8 \%$ found by Precioso et al among children from Azores. ${ }^{22}$ This finding may reveal that more information regarding the negative effects of SHS in children's health should be provided to the population.

One limitation of this study is that it relied on self-reported measures. Although the level of exposure to SHS can be assessed by the measurement of cotinine, nicotine metabolites, plasma, urine, saliva, and carbon monoxide in exhaled air, we decided to administer a questionnaire as it was more practical and economical, and as there is a positive correlation between the exposure assessed by questionnaires and the cotinine levels in children. It would be useful to have explored differences between gender among children, and to have administered a measure of well-being to adults and children in order to analyse associations between well-being and SHS at home and inside the car.

\section{CONCLUSION}

SHS exposure at home has been decreasing, and people in Portugal smoke less at home than in the majority of the European countries, probably due to the low prevalence of smokers in Portugal and the impact of tobacco control policies. ${ }^{12}$ However, it is still crucial to implement effective parental smoking control measures, as the main source of children's exposure to SHS is parental smoking. Smoking cessation consultations should be reinforced in order to reduce the prevalence of parents who smoke and, consequently, to prevent children's exposure to SHS.

Smoking control policies and prevention of SHS exposure should also focus on health education campaigns in order to increase awareness about the negative effects of SHS. It would be useful to analyze false myths and beliefs associated with SHS exposure such as "smoking inside the car, when the child is not present, is harmless" or "smoking in the kitchen or near a window at home does not expose children to SHS". The school, the community and healthcare professionals should proactively work and collaborate in order to achieve this goal. Teachers and health professionals can play an important role preventing tobacco consumption at home, suggesting that it is desirable that parents do not smoke or, at least, do not smoke at home or inside the car, and not in the presence of their children, in order to prevent SHS exposure and children becoming smokers in the future. It is crucial to implement effective preventive interventions to reduce the prevalence of children exposed to SHS and to increase home and cars that are $100 \%$ smoke-free. Banning smoking inside the car should also be implemented, in order to protect children from exposure to SHS, and to avoid car accidents.

\section{PROTECTION OF HUMANS AND ANIMALS}

The authors declare that the procedures were followed according to the regulations established by the Clinical Research and Ethics Committee and to the Helsinki Declaration of the World Medical Association.

\section{DATA CONFIDENTIALITY}

The authors declare having followed the protocols in use at their working center regarding patients' data publication.

\section{CONFLICTS OF INTEREST}

The authors declare they have no conflicts of interest for this manuscript. 


\section{FUNDING SOURCES}

Study funded by the Direção Geral da Saúde, project: No458/2014/DGS.

\section{REFERENCES}

1. California Environmental Protection Agency: Air Resources Board. Proposed identification of environmental tobacco smoke as a toxic air contaminant; 2005. [consultado 2011 nov 28]. Disponível em: http:// oehha.ca.gov/air/environmental_tobacco/pdf/app3partb2005.pdf.

2. International Agency for Research on Cancer. IARC monographs on the evaluation of carcinogenic risks to humans; 2002, [accessed 2007 Sep 5]. Disponível em: http://monographs.iarc.fr/ENG/Monographs/ vol83/volume83.pdf,

3. U.S. Department of Health and Human Services. Children and secondhand smoke exposure. The health consequences of involuntary exposure to tobacco smoke: a report of the Surgeon General. Atlanta: U.S. Department of Health and Human Services; 2006.

4. Behr J, Nowak D. Tobacco smoke and respiratory disease. Eur Respir J. 2002;21:161-79.

5. Pestana E, Neves P, Borges M, Matias D, Mendes B, Moreira S, et al Tabagismo - do diagnóstico ao tratamento. Lisboa: LIDEL Edições Técnicas; 2006

6. Öberg M, Jaakkola M, Woodward A, Peruga A, Prüss-Ustün A. Worldwide burden of disease from exposure to second-hand smoke: A retrospective analysis of data from 192 countries. Lancet. 2011;377:139-46.

7. Lieu J, Feinstein A. Effect of gestational and passive smoke exposure on ear infections in children. Arch Pediatr Adolesc Med. 2002;156:147-54.

8. World Health Organization. WHO report on the global tobacco epidemic, 2009. Geneva: WHO; 2009.

9. Oddoze C, Dubus J, Badier M, Thirion X, Pauli A, Pastor J, et al. Urinary cotinine and exposure to parental smoking in a population of children with asthma. Clin Chem. 1999;45:505-9.

10. Sly P, Deverell M, Kusel M, Holt P. Exposure to environmental tobacco smoke in cars increases the risk of persistent wheeze in adolescents. Med J Aust. 2007;186:322.

11. Jones M, Navas-Acien A, Yuan J, Breysse P. Secondhand tobacco smoke concentrations in motor vehicles: a pilot study. Tob Control. 2009;18:399-404.
12. European Comission. Tobacco: Special Eurobarometer 332. Brussels: European Comission; 2010.

13. Moore G, Holliday J, Moore L. Research into the impact of smoke-free legislation in Wales: Childhood exposure to environmental tobacco smoke Wales. Cardiff: Cardiff Institute of Society, Health and Ethics; 2008.

14. Precioso J, Araújo C, Machado J, Samorinha C, Becoña E, Ravara S, et al. A educação para a saúde na proteção das crianças da exposição ao fumo ambiental do tabaco. Educação, Sociedade, \& Culturas. 2013;38:13-29

15. World Health Organization. Second hand tobacco smoke; 2007 [accessed 2007 Jul 9]. Disponível em: http://www.who.int/tobacco/ research/secondhand_smoke/en/.

16. Precioso J, Samorinha C, Calheiros J, Macedo M, Antunes H, Campos H. Exposição das crianças ao fumo ambiental do tabaco: Avaliação de uma intervenção preventiva. Rev Port Pneumol. 2010;16:57-72.

17. Vitória P, Nunes $C$, Precioso J. Parents' educational level and secondhand tobacco smoke exposure at home in a sample of Portuguese children. Rev Port Pneumol. 2017;23:221-24.

18. Orton S, Jones L, Cooper S, Lewis S, Coleman T. Predictors of children's secondhand smoke exposure at home: a systematic review and narrative synthesis of the evidence. PLoS One. 2014;9:e112690.8.

19. Brown K, Palmersheim K, Glysch R. Factors associated with youth smoking in Wisconsin. Wisconsin: University of Wisconsin; 2008.

20. Precioso J, Macedo M, Rebelo L. Relação entre o tabagismo dos pais e o consumo de tabaco dos filhos: Implicações para a prevenção. Rev Port Med Geral Fam. 2007;23:259-66.

21. Precioso J, Araújo C, Samorinha C, Machado J, Becoña E, Ravara S, et al. Exposição das crianças ao fumo ambiental do tabaco em casa e no carro. Millenium. 2012:42;7-25.

22. Precioso J, Frias S, Silva C, Rocha V, Machado J, Gonçalves F, et al. Prevalence of children exposed to secondhand smoke at home and in the car in Azores (Portugal). Pulmonology. 2019. [In Press]. 